\title{
Morphological and biochemical characterization of locally available kidney beans
}

\author{
Abbas Ali*, Sher Aslam Khan, Sardar Ali, Naushad Ali, Shah Masaud \\ Khan, Izhar Hussain, Taufeeq Ahmad, Abdul Basit and Haneef Raza \\ Department of Agricultural Science, University of Haripur-Pakistan \\ *Corresponding author's email: abbas2938@gmail.com \\ Citation \\ Abbas Ali, Sher Aslam Khan, Sardar Ali, Naushad Ali, Shah Masaud Khan, Izhar Hussain, Taufeeq Ahmad, Abdul \\ Basit and Haneef Raza. Morphological and biochemical characterization of locally available kidney beans. Pure and \\ Applied Biology.Vol. 9, Issue 1, pp528-537. http://dx.doi.org/10.19045/bspab.2020.90058
}

\begin{tabular}{llll}
\hline \hline Received: 01/08/2019 & Revised: 06/11/2019 & Accepted: 18/11/2019 & Online First: 06/12/2019 \\
\hline
\end{tabular}

\section{Abstract}

The present research study was aimed for estimation of genetic diversity and characterization of various morphological and biochemical traits of kidney beans (Phaseolus vulgaris L.) with the objectives of identifying superior genotypes at the Research Farm, The University of Haripur during zaid-rabi season 2018. Twelve different kidney bean genotypes were evaluated by using Randomize Complete Block Design (RCBD) with three replications. Data was recorded for various morphological and biochemical traits. Analysis of variancerevealed highly significant genetic diversity.Minimum days to emergence were recorded for Line-12 (22.66 days), having moderate plant height of $(89.44 \mathrm{~cm})$, longer pods $(13.003 \mathrm{~cm})$ containing maximum number of seeds (6.55). Minimum days to flowering were observed for Line-1 (59 days). Maximum plant height was recorded for Line-5 $(99.11 \mathrm{~cm})$. Maximum numbers of pods were produced by Line-9 having (16.28). Maximum pod length $(13.55 \mathrm{~cm})$ was observed for Line-2. Seeds per plant were maximum in Line-9 (72.97). Line 4 produced larger size bean seeds having maximum 100 seed weight $(55.74 \mathrm{~g})$. Total phenolic compounds were observed to be maximum in Line-10 (88.24 $\mathrm{mg} / 100 \mathrm{~g}$ ) while total antioxidants were maximum in Line-7 (136.88). Based on the characterization of kidney bean genotypes at Haripur, the genotypes viz. Line-9 and Line-12 were observed superior having minimum days to emergence, moderate plant height, early maturity, high yield. Therefore, these genotypes are recommended for further characterization in the kidney bean breeding programfor further evaluation.

Keywords: Antioxidants; Characterization; Genetic diversity; Phenolic compounds

\section{Introduction}

Kidney bean Phaseolus vulgaris L. is selfpollinated diploid specie of the genus Phaseolus having 22 chromosomes. Most of the species of the genus phaseolus are of wild type however only 5 are known to be cultivated viz. Phaseolus acutifolius (tepary bean), Phaseolus coccineus L. (scarlet runnerbean), Phaseolus lunatus L. (lima bean), Phaseoluspolyanthus (year-long bean) and Phaseolus vulgaris L. (common bean) [1, 2]. The origin of Phaseolus vulgaris dates back to $6500-5000 \mathrm{BC}$ [3]. Common beans perform better in tropical and subtropical 
regions having average rainfall. It grows well in the areas which are dry having suitable conditions for the maize cultivation $[4,5]$.

From nutritional point of view, common beans are rich source of proteins, almost providing 3 times more protein than that of cereal grains [6]. Common bean dry seeds are rich in vitamins, minerals, starch and dietary fibers [7] and are also contains variety of phytochemicals, antioxidants, flavonoids such as anthocyanin's, pro-anthocyanin's, lectins, phytates, flavonols, phenolic acids and iso-flavones [8-10]. Consumption of common beans is greatly associated with many physiological and health benefits and ultimately results in the reduction of cardiac diseases, obesity, diabetes mellitus and carcinogenic diseases [11, 12]. During 2018, worldwide production of common bean was 27 million tons. Myanmar produced the largest amount of dried beans and on the other hand China was the largest producer of green beans. In Northern America, production of dry kidney beans is $1 \mathrm{t} / \mathrm{ha}$ and throughout the worldwide it is $0.7 \mathrm{t} / \mathrm{ha}$. In Africa, average yield is around $0.6 \mathrm{t} / \mathrm{ha}$. Breeding programs initially started in Africa and its native regions with the aim of improving yield potential. Their major objective is to induce tolerance and resistance to biotic and abiotic factors. In Pakistan, the average yield of kidney bean is about $0.5 \mathrm{t} / \mathrm{ha}$. In irrigated areas, using best agronomic and cultural practices, they yield 2.5-5 t/ha. Consumption of kidney bean in Pakistan is more than its production. Henceforth, huge amount is spent on its import every year. Identification of promising and high yielding kidney bean genotypes will not only lead to self-sufficiency but will also minimizes its import through foreign exchange [13].

There are more than 20 species of legumes which are consumed as dry grains in plenty amounts as a human nutrition $[6,12]$. Phaseolus vulgaris L. (common bean) is one of the most abundantly used leguminous crop. Generally common beans are considered as a vital source of nutrients and are also known as poor man's meat [14]. In the third world countries, legumes especially common beans and soybean are considered to be of great importance for their consumption as a food where malnutrition seems to be prominent due to protein deficiency. Throughout the world and particularly in the developing countries, common beans are consumed now days [15].

Many factors are correlated with its yield ultimately influencing the pods productivity. In order to achieve higher yield and improve its productivity, it is necessary to maintain balance between vegetative and reproductive traits. It is a very difficult task to be achieved because all those morphological traits which are positive correlated with yield are not static due to genotype by environmental interaction. Still there are multiple ways of breeding common bean and selection of superior common bean land races is one of the methods $[16,17]$. Beside the fact that common beans are of great potential and importance, still no research has been carried out in Pakistan. The exploitation of local genetic resources could solve some issues regarding the identification of some characters which ultimately enhance the yield and are important for plant breeding $[18,19]$. Therefore, an experiment was designed and conducted at the Research Farm, The University of Haripur for the characterization of various morphological and biochemical traits with the objectives of identifying superior kidney beans genotypes having high yield and improved biochemical components (Figure 1). Before the recommendation of these kidney bean genotypes for general cultivation, they will be further characterized in the kidney bean breeding program.

\section{Materials and methods}

A research was designed to assess morphological and yield characteristics of 
twelve different kidney bean genotypes during zaid-rabi season 2018, at the University of Haripur 33 $39^{\circ}$ ' North and 72 $56^{\prime}$ 'East with altitude of 610 meters. These genotypes were collected from upper hilly areas of Khyber Pakhtunkhwa. Sowing was completed on $26^{\text {th }}$ January, 2018 using randomized complete block design (RCBD) with three replications. Data was recorded on various traits viz., days to emergence (DE), days to flowering (DF), plant height (PH), pods plant ${ }^{-1}\left(\mathrm{PP}^{-1}\right)$, pod length (PL), seeds $\operatorname{pod}^{-1}\left(\mathrm{SP}^{-1}\right)$, seed yield plant $^{-1}\left(\mathrm{SYP}^{-1}\right), 100$ seed weight ( $\mathrm{SW}$ ), total phenolic compounds (TPC) and total antioxidnats (TA). Means of all the traits were calculated and subjected to statistical analysis (statistics 8.1) for analysis of variance (ANOVA) and LSD test was used to find least significant differences as per the method described by [20] (Table 1).

Table 1 List of the experimental material

\begin{tabular}{|c|c|c|}
\hline S. No. & Germplasm & Source \\
\hline 1 & Line 1 & Hungu, Khyber Pakhtunkhwa \\
\hline 2 & Line 2 & Kalam, Upper Swat \\
\hline 3 & Line 3 & Parachinnar I, \\
\hline 4 & Line 4 & Tal Lamutai, Upper Dir \\
\hline 5 & Line 5 & Kadda, Parachinar, \\
\hline 6 & Line 6 & Tirah I, Parachinnar \\
\hline 7 & Line 7 & Tirah II, Parachinnar \\
\hline 8 & Line 8 & Kurram \\
\hline 9 & Line 9 & Naran, Mansehra \\
\hline 10 & Line 10 & Shiringal, Upper Dir \\
\hline 11 & Line 11 & Parachinar II \\
\hline 12 & Line 12 \\
\hline
\end{tabular}

\section{Results and discussion}

Emergence refers to the germination of seedling from the soil. The process of germination initiates when water is absorbed by the seed. Days to emergence showed significant differences for all genotypes (Table 2). The said trait ranged between 28 to 22.66 days. Mean value for days to emergence was recorded to be 25.11 days. Maximum (DE) were recorded for Line-10 (28 days) followed by Line-7 (27.33 days) and Line-2 (26.66 days). While least (DE) were recorded for Line-12 (22.66 days) followed by Line-6 (23 days) (Table 3 ). The observed genotypic and phenotypic variability can be correlated to the environmental conditions from where these genotypes were collected. [21-23] also conducted experiments on kidney beans and their findings were also significant for (DE) in kidney bean. However, their mean values are different form our results. This may be due difference in soil moisture content, genetic makeup of the genotypes used in the current study, $\mathrm{pH}$ level of soil and different environmental conditions of study area.

Flower is the colorful and reproductive part of the angiosperm plants. The main function of flower is to affect the process of reproduction. All the genotypes varied highly significantly from each other regarding days to flowering and ranged from 72.00 to 59.33 days (Table 2). Mean of the data was recorded to be 65.67 days. Maximum (DF) were recorded in Line-12 (72.00 days) followed by Line-6 (70.00 days), Line-8 (68.00days) and Line-3 (67.33 days). On the hand, Line-1 (59.33 days) took minimum (DF) (Table 3). Significant results were also obtained by $[24,25]$ which are similar to results of the present study. 
The character plant height is controlled by many genes and is polygenic in nature. It is also influenced by the environment. The phenomenon of additive gene action is always involved in it. Therefore, it cannot be static and always perform differently even in the same environmental conditions. In the current study, plant height exhibited significant variability and varied from 99.11 $\mathrm{cm}$ to $30.37 \mathrm{~cm}$ (Table 2). Mean plant height was noted to be $54.89 \mathrm{~cm}$. Maximum (PH) was recorded for Line-5 $(99.11 \mathrm{~cm})$ followed by Line- $6(93.11 \mathrm{~cm})$ and Line- $12(89.44 \mathrm{~cm})$ while minimum $(\mathrm{PH})$ was observed for Line$1(30.37 \mathrm{~cm})$ followed by Line-3 $(52.27 \mathrm{~cm})$ (Table 3). The results of present study are in confirmation with the results of previous findings of $[5,26]$ that significant differences are present for the plant height.

In kidney bean, flowering is followed by pods formation. Pods contain seeds, the edible part of the bean plant. Analysis of the current study revealed that pods per plant in kidney bean genotypes varied significantly from each other (Table 2). Mean value for pods per plant was 11.81. The whole data was dispersed between 16.28 and 6.89. Maximum $\left(\mathrm{PP}^{-1}\right)$ were obtained from Line-9 (16.28) followed by Line-11(15.66) and Line-5 (15.13) while least values were obtained from Line-1 (6.89), Line-12 (8.58) and Line-4 (9.16) (Table 3). From analysis of variance, genotype mean square value and coefficient of variance was 29.04 and $25.08 \%$ respectively. [27] Studied and reported that significant differences are present in kidney bean. However their results are different from our findings because of the difference in genetic material used and different climatic conditions.

Pod length is polygenic trait and affected by several genes. It is also influenced by environment. The process of domestication in kidney bean led to development of large pods rather than small pods. For pod length, genetic variability was present in kidney bean genotypes. Data varied significantly from each other (Table 2). Mean value was 11.16 $\mathrm{cm}$ for (PL). The data ranged between 13.55 $\mathrm{cm}$ to $8.44 \mathrm{~cm}$. Maximum value for (PL) was obtained for Line-2 (13.55 cm), Line-6 $(13.11 \mathrm{~cm})$ and Line-12 $(13.00 \mathrm{~cm})$ while minimum value was recorded for Line-1 $(8.44) \mathrm{cm}$, Line-8 $(9.11 \mathrm{~cm})$ and Line-3 $(9.22$ $\mathrm{cm})$ (Table 3). [5, 28] also reported genetic variability for (PL) in their studies on kidney bean. However their results differ from our findings. The reason might be due to difference in genetic make-up, polygenic nature of the trait and experimental area.

Seeds, the edible portion of kidney bean, are present inside the pod. Number of seeds varies from plant to plant and also varies from genotype to genotype. Seed per plant is highly variable character. Number of $\left(\mathrm{SP}^{-1}\right)$ varied significantly from the mean value (Table 2). The data varied from 6.55 to 3.64. Mean value for number of $\left(\mathrm{SP}^{-1}\right)$ was recorded to be 4.65. Maximum number of $\left(\mathrm{SP}^{-1}\right)$ were obtained from Line-12 (6.55) followed by Line-6 (5.76) and Line-7 (4.92). Minimum value for the trait was observed in Line-1 (3.64) followed by Line-10 and Line11 having $3.89\left(\mathrm{SP}^{-1}\right)$ each (Table 3$)$. Results of the current study are in confirmation with the results of the research study conducted by [29]. These researchers also reported that variability exits among kidney bean genotypes for number of $\left(\mathrm{SP}^{-1}\right)$.

Improving the final yield is one of the most important objectives of plant breeding. Many researchers are focusing to improve the yield of any crop to meet the challenges of the growing population. Yield is quantitative trait and is controlled by many genes. Additive and epistatic gene action is involved in it. Minor and major genes contribute towards the final yield. Data was collected on seed yield per plant and analysis showed that significant genetic differences are present in the kidney bean genotypes (Table 2). Line-7 $(72.97 \mathrm{~g})$ exhibited maximum $\left(\mathrm{SYP}^{-1}\right)$ 
followed by Line-11 and Line-12 having values of $(71.10 \mathrm{~g})$ and $(69.24 \mathrm{~g})$ respectively. Minimum $\left(\mathrm{SYP}^{-1}\right)$ was recorded in Line-1 having value of (25.77 $\mathrm{g}$ ) followed by Line-10 (34.83 g) and Line-4 (45.02 g) (Table 3). Mean value of the trait was found to be 54.89 g. Similar results were also obtained by [30]. However there is difference between the genotype mean square values and coefficient of variation of the current study and previous analysis which might be due to environmental factors, polygenic nature of the trait and difference in experimental area.

Seed weight is important and critical for any seed crop yield. It is important to understand the genetic mechanism for improving the seed yield. Many candidate genes are involved in controlling the said trait. Seed is the economic part of kidney bean plant which is enclosed within the pod. Size of the seed varies from variety to variety and also from plant to plant of the same variety. Seed weight is measured in grams. Data was recorded on 100 seed weight and analysis of variance showed that highly significant variability is present (Table 2). Mean value for $100(\mathrm{SW})$ was recorded to be $37.51 \mathrm{~g}$. The whole data ranged from $55.74 \mathrm{~g}$ to $19.74 \mathrm{~g}$. Maximum value for the trait was obtained from Line-4 (55.74 $\mathrm{g}$ ) followed by Line-2 (44.88 g). Minimum value for 100 (SW) was observed in Line-3 (19.74 g) (Table 3). The findings of our current study are in confirmation with findings of studies conducted by $[31,32]$. However there are differences in the mean data and range which might be due to difference in genotypes and climatic conditions of the current study.

Phenolic compounds include simple phenols, phenolic acids, hydroxycinnamic acid derivatives and flavonoids are bioactive compounds produced by numerous plants having anti-inflammatory and anti-allergic functions. Among the kidney bean genotypes, total phenolic compounds varied highly significantly from each other (Table 4). Maximum concentration of (TPC) was present in Line-10 (88.24 mg/100g) followed by Line-7 and Line-11 having values of 85.80 $\mathrm{mg} / 100 \mathrm{~g}$ and $75.61 \mathrm{mg} / 100 \mathrm{~g}$ respectively (Table 5). Antioxidant activity and genetic variability of (TPC) present in kidney beans was also reported by [33].

Antioxidants are the chemical substances having the capability to inhibit oxidation. Oxidation is a chemical reaction that can produce free radicals leading to damage the cells of an organism. Total antioxidant activity of all the genotypes of kidney bean varied highly significantly from each other (Table 4). Maximum concentration of (TA) was obtained for Line-7 (136.88) followed by Line-10 (135.96) and Line-12 (135.95). Minimum values were recorded in Line-6 (131.67) followed by Line-5 (132.17) and Line3 (133.42) (Table 5). [34, 35] Studied the antioxidant activity of kidney beans and reported that genetic variability exists among the kidney bean genotypes for the said biochemical compound. 
a

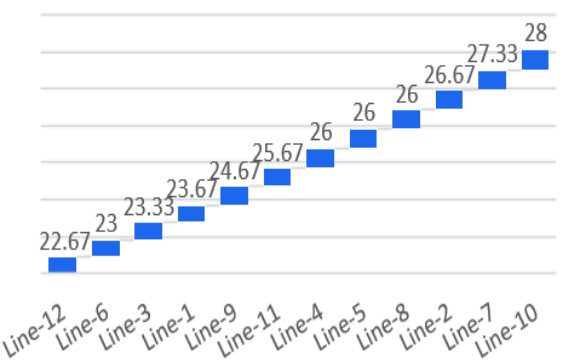

e

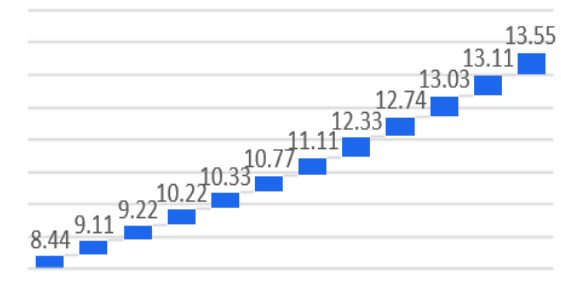

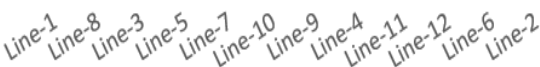

b Days to flowering

$\overline{\overline{50}}$
$59.33^{60.33^{64.33^{65}}}$

f

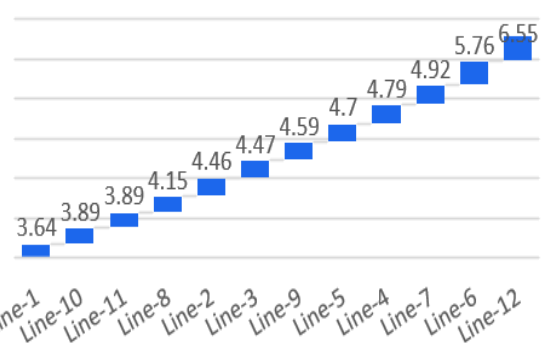

i Total Phenolic Compounds

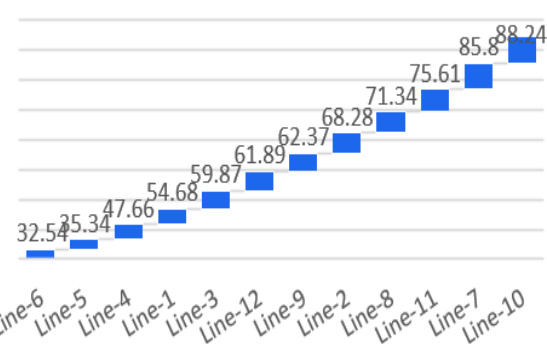

\section{Plant Height}

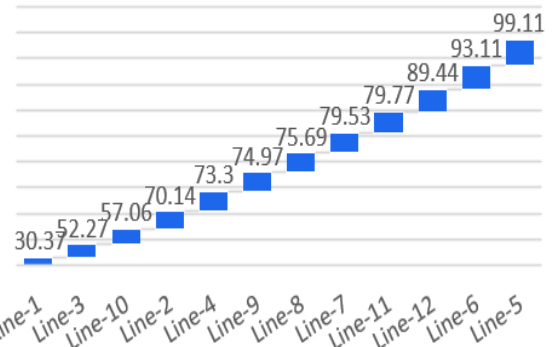

g Seed Yield Per Plant

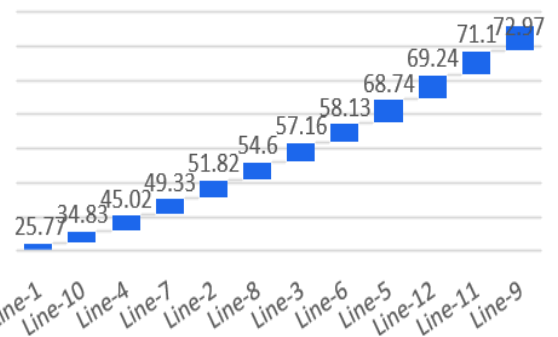

j Total Antioxidents

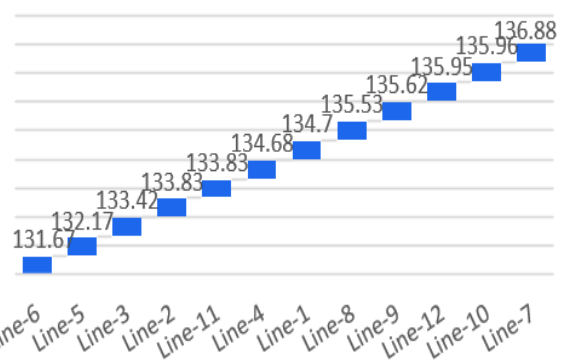

d

Pods Per Plant

$\frac{\bar{c} 115.67}{16.28}$

h 100-Seed Weight

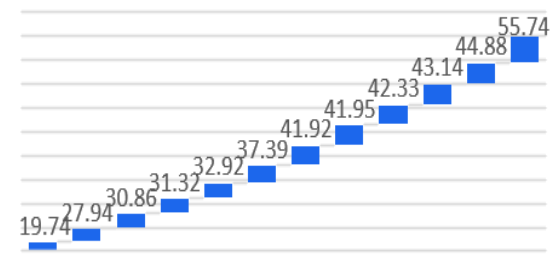

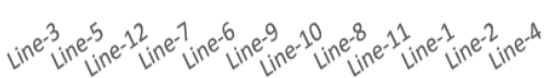

Figure 1. Variability of kidney bean genotypes for various morphological and biochemical traits 
Table 2. Mean squares with CV (\%) for days to emergence, days to flowering, plant height, pods plant $^{-1}$, pod length, seeds pod $^{-1}$, seed yield plant ${ }^{-1}$ and 100 seed weight in Kidney bean (Phaseolus vulgaris L.)

\begin{tabular}{|c|c|c|c|c|c|}
\hline Traits & Replication & Genotypes & Error & F. Ratio & CV (\%) \\
\hline Days to Emergence & 8.11 & $7.47^{*}$ & 3.14 & 2.38 & 7.06 \\
\hline Days to Flowering & 9.75 & $39.15^{* *}$ & 3.99 & 9.81 & 3.04 \\
\hline Plant Height & 1825.17 & $1081.50^{* *}$ & 250.12 & 4.32 & 21.69 \\
\hline Pods per Plant & 33.38 & $29.04 * *$ & 8.78 & 3.31 & 25.08 \\
\hline Pod Length & 1.40 & $9.24 * *$ & 2.22 & 4.14 & 13.38 \\
\hline Seeds per Pod & 0.092 & $2.033^{*}$ & 0.883 & 2.30 & 20.21 \\
\hline Seed Yield per Plant & 944.30 & $652.08^{*}$ & 253.49 & 2.57 & 29.00 \\
\hline 100 Seed Weight & 172.61 & $270.48^{* *}$ & 47.38 & 5.71 & 18.35 \\
\hline
\end{tabular}

* = Significant at $p \leq 0.05$

$* *=$ Significant at $p \leq 0.01$

Table 3. Mean values of days to emergence, days to flowering, plant height,pods plant ${ }^{-1}$, pod length, seeds pod ${ }^{-1}$, seed yield plant ${ }^{-1}$ and 100 seed weight in Kidney bean (Phaseolus vulgaris L.).

\begin{tabular}{|c|c|c|c|c|c|c|c|c|}
\hline $\begin{array}{c}\text { Genoty } \\
\text { pes }\end{array}$ & $\begin{array}{c}\text { Days to } \\
\text { emergence }\end{array}$ & $\begin{array}{c}\text { Days to } \\
\text { flowering }\end{array}$ & $\begin{array}{c}\text { Plant } \\
\text { height }\end{array}$ & $\begin{array}{c}\text { Pods per } \\
\text { Plant }\end{array}$ & $\begin{array}{c}\text { Pod } \\
\text { Length }\end{array}$ & $\begin{array}{c}\text { Seeds } \\
\text { per pod }\end{array}$ & $\begin{array}{c}\text { Seed } \\
\text { yield per } \\
\text { Plant }\end{array}$ & $\begin{array}{c}\text { 100 Seed } \\
\text { Weight }\end{array}$ \\
\hline Line-1 & $23.67 \mathrm{c}-\mathrm{d}$ & $59.33 \mathrm{e}$ & $30.37 \mathrm{e}$ & $6.89 \mathrm{e}$ & $8.44 \mathrm{e}$ & $3.64 \mathrm{c}$ & $25.77 \mathrm{~d}$ & $43.14 \mathrm{~b}-\mathrm{c}$ \\
\hline Line-2 & $26.67 \mathrm{a}-\mathrm{c}$ & $64.33 \mathrm{~d}$ & $70.14 \mathrm{~b}-\mathrm{d}$ & $10.70 \mathrm{~b}-\mathrm{e}$ & $13.55 \mathrm{a}$ & $4.46 \mathrm{~b}-\mathrm{c}$ & $51.82 \mathrm{a}-\mathrm{d}$ & $44.88 \mathrm{a}-\mathrm{b}$ \\
\hline Line-3 & $23.33 \mathrm{de}$ & $67.33 \mathrm{~b}-\mathrm{d}$ & $52.27 \mathrm{~d}-\mathrm{e}$ & $13.46 \mathrm{a}-\mathrm{d}$ & $9.22 \mathrm{~d}-\mathrm{e}$ & $4.47 \mathrm{~b}-\mathrm{c}$ & $57.16 \mathrm{a}-\mathrm{c}$ & $19.74 \mathrm{f}$ \\
\hline Line-4 & $26.00 \mathrm{a}-\mathrm{d}$ & $60.00 \mathrm{e}$ & $73.30 \mathrm{a}-\mathrm{d}$ & $9.16 \mathrm{~d}-\mathrm{e}$ & $12.33 \mathrm{a}-\mathrm{c}$ & $4.79 \mathrm{~b}-\mathrm{c}$ & $45.02 \mathrm{~b}-\mathrm{d}$ & $55.74 \mathrm{a}$ \\
\hline Line-5 & $26.00 \mathrm{a}-\mathrm{d}$ & $65.00 \mathrm{c}-\mathrm{d}$ & $99.11 \mathrm{a}$ & $15.13 \mathrm{a}-\mathrm{c}$ & $10.22 \mathrm{c}-\mathrm{e}$ & $4.70 \mathrm{~b}-\mathrm{c}$ & $68.74 \mathrm{a}-\mathrm{b}$ & $27.94 \mathrm{e}-\mathrm{f}$ \\
\hline Line-6 & $23.00 \mathrm{~d}-\mathrm{e}$ & $70.00 \mathrm{a}-\mathrm{b}$ & $93.11 \mathrm{a}-\mathrm{b}$ & $11.33 \mathrm{a}-\mathrm{e}$ & $13.11 \mathrm{a}-\mathrm{b}$ & $5.76 \mathrm{a}-\mathrm{b}$ & $58.13 \mathrm{a}-\mathrm{c}$ & $32.92 \mathrm{c}-\mathrm{e}$ \\
\hline Line-7 & $27.33 \mathrm{ab}$ & $64.33 \mathrm{~d}$ & $79.53 \mathrm{a}-\mathrm{c}$ & $10.57 \mathrm{c}-\mathrm{e}$ & $10.33 \mathrm{c}-\mathrm{e}$ & $4.92 \mathrm{~b}-\mathrm{c}$ & $49.33 \mathrm{a}-\mathrm{d}$ & $31.32 \mathrm{~d}-\mathrm{f}$ \\
\hline Line-8 & $26.00 \mathrm{a}-\mathrm{d}$ & $68.00 \mathrm{~b}-\mathrm{c}$ & $75.69 \mathrm{a}-\mathrm{d}$ & $14.55 \mathrm{a}-\mathrm{c}$ & $9.11 \mathrm{~d}-\mathrm{e}$ & $4.15 \mathrm{c}$ & $54.60 \mathrm{a}-\mathrm{c}$ & $41.95 \mathrm{~b}-\mathrm{d}$ \\
\hline Line-9 & $24.67 \mathrm{~b}-\mathrm{e}$ & $66.00 \mathrm{c}-\mathrm{d}$ & $74.97 \mathrm{a}-\mathrm{d}$ & $16.28 \mathrm{a}$ & $11.11 \mathrm{a}-\mathrm{d}$ & $4.59 \mathrm{~b}-\mathrm{c}$ & $72.97 \mathrm{a}$ & $37.39 \mathrm{~b}-\mathrm{e}$ \\
\hline Line-10 & $28.00 \mathrm{a}$ & $66.00 \mathrm{c}-\mathrm{d}$ & $57.06 \mathrm{c}-\mathrm{e}$ & $9.44 \mathrm{~d}-\mathrm{e}$ & $10.77 \mathrm{a}-\mathrm{d}$ & $3.89 \mathrm{c}$ & $34.83 \mathrm{c}-\mathrm{d}$ & $41.92 \mathrm{~b}-\mathrm{d}$ \\
\hline Line-11 & $25.67 \mathrm{a}-\mathrm{e}$ & $65.66 \mathrm{c}-\mathrm{d}$ & $79.77 \mathrm{a}-\mathrm{c}$ & $15.67 \mathrm{a}-\mathrm{b}$ & $12.74 \mathrm{a}-\mathrm{c}$ & $3.89 \mathrm{c}$ & $71.10 \mathrm{a}-\mathrm{b}$ & $42.33 \mathrm{~b}-\mathrm{d}$ \\
\hline Line-12 & $22.67 \mathrm{e}$ & $72.00 \mathrm{a}$ & $89.44 \mathrm{a}-\mathrm{b}$ & $8.58 \mathrm{~d}-\mathrm{e}$ & $13.03 \mathrm{a}-\mathrm{b}$ & $6.55 \mathrm{a}$ & $69.24 \mathrm{a}-\mathrm{b}$ & $30.86 \mathrm{~d}-\mathrm{f}$ \\
\hline $\begin{array}{c}\text { LSD } \\
(\mathbf{0 . 0 5}\end{array}$ & $\mathbf{3 . 0 3 1 2}$ & $\mathbf{3 . 3 8}$ & $\mathbf{2 6 . 7 8}$ & $\mathbf{5 . 0 1}$ & $\mathbf{2 . 5 2}$ & $\mathbf{1 . 5 9}$ & $\mathbf{2 6 . 9 6}$ & $\mathbf{1 1 . 6 5}$ \\
\hline
\end{tabular}

Means followed by the same letter are not significantly different from each other 
Table 4. Mean squares with CV (\%) for Total Phenolic Compounds and Total antioxidants estimated in kidney bean (Phaseolus vulgaris $\mathbf{L}$.)

\begin{tabular}{|c|c|c|c|c|c|}
\hline Phytochemicals & Replication & Genotypes & Error & F. Ratio & CV (\%) \\
\hline Total Phenolic Compounds & 0.96 & $929.81^{* *}$ & 0.96 & 965.70 & 1.58 \\
\hline Total antioxidants & 0.68 & $7.56^{* *}$ & 1.41 & 5.36 & 0.88 \\
\hline
\end{tabular}

$*=$ Significant at $p \leq 0.05$

$* *=$ Significant at $p \leq 0.01$

Table 5. Mean values of Total Phenolic Compounds and Total antioxidants in kidney bean (Phaseolusvulgaris L.)

\begin{tabular}{|c|c|c|}
\hline Genotypes & Total Phenolic Compounds & Total antioxidants \\
\hline Line-1 & $54.68 \mathrm{~h}$ & $134.70 \mathrm{~b}-\mathrm{d}$ \\
\hline Line-2 & $68.28 \mathrm{e}$ & $133.83 \mathrm{c}-\mathrm{e}$ \\
\hline Line-3 & $59.87 \mathrm{~g}$ & $133.42 \mathrm{~d}-\mathrm{f}$ \\
\hline Line-4 & $47.66 \mathrm{i}$ & $134.68 \mathrm{~b}-\mathrm{d}$ \\
\hline Line-5 & $35.34 \mathrm{j}$ & $132.17 \mathrm{e}-\mathrm{f}$ \\
\hline Line-6 & $32.54 \mathrm{k}$ & $131.67 \mathrm{f}$ \\
\hline Line-7 & $85.80 \mathrm{~b}$ & $136.88 \mathrm{a}$ \\
\hline Line-8 & $71.34 \mathrm{~d}$ & $135.53 \mathrm{a}-\mathrm{c}$ \\
\hline Line-9 & $62.37 \mathrm{f}$ & $135.62 \mathrm{a}-\mathrm{c}$ \\
\hline Line-10 & $88.24 \mathrm{a}$ & $135.96 \mathrm{a}-\mathrm{b}$ \\
\hline Line-11 & $75.61 \mathrm{c}$ & $133.83 \mathrm{c}-\mathrm{e}$ \\
\hline Line-12 & $61.89 \mathrm{f}$ & $135.95 \mathrm{a}-\mathrm{b}$ \\
\hline LSD $(\mathbf{0 . 0 5})$ & $\mathbf{1 . 6 6}$ & $\mathbf{2 . 0 1 1}$ \\
\hline
\end{tabular}

Means followed by the same letter are not significantly different from each other

\section{Conclusion and recommendations}

Analysis of variance revealed that all the genotypes were significantly different regarding various morphological and biochemical traits which confirms the presence of genetic diversity. Minimum days to emergence were recorded for Line-12 (22.66 days), having moderate plant height of $(88.17 \mathrm{~cm})$, longer pods $(13.003 \mathrm{~cm})$ containing maximum number of seeds (6.55). Minimum days to flowering were observed for Line-1 (59 days). Maximum plant height was recorded for Line-5 $(95.66 \mathrm{~cm})$. Maximum number of pods (16.28) was produced by Line- 9 , having maximum seeds per plant (72.97 seeds). Maximum pod length $(13.55 \mathrm{~cm})$ was observed for Line-2. Line 4 produced large size seeds having maximum 100 seed weight $(55.74 \mathrm{~g})$.Total phenolic compounds and total antioxidants were observed to be maximum in Line-10 (88.24 $\mathrm{mg} / 100 \mathrm{~g}$ ) and Line-7 (136.88) respectively. Although, all these genotypes were collected were collected from their natural habitat, most of them performed well at subtropical climatic region of Haripur. Based on the characterization of kidney bean genotypes at Haripur, the genotypes viz. Line-9 and Line12 were observed having minimum days to emergence, moderate plant height and high yield. Therefore, these genotypes are recommended for further characterization in the kidney bean breeding program.

Authors' contributions 
Conceived and designed the experiments: A Ali \& SA Khan, Performed the experiments: T Ahmad \& A Basit, Analyzed the data: I Hussain, Contributed materials/ analysis/ tools: S Ali, N Ali \& SM Khan, Wrote the paper: H Raza.

\section{Acknowledgments}

I am greatly indebted and pay special thanks to my kind and pre-eminent supervisor Dr. Sher Aslam Khan for his sincere and continuous efforts, constant supervision, friendly attitude, support and judicious guidance that afforded solace of mind and encouragement in accomplishment of the task throughout the period of this study.

\section{References}

1. Debouck DG (1999). Diversity in Phaseolus species in relation to the common bean. In Common bean improvement in the twenty-first century. Springer, Dordrecht 1999(1): 25-52.

2. Gepts P \& Debouck D (1991). Origin, domestication and evolution of the common bean. Hort Sci 73(3): 721-729.

3. Kaplan L, Lynch TF \& Smith CE (1973). Early cultivated beans (Phaseolus vulgaris) from an inter-mountain Peruvian valley. Sci 179(4068): 76-77.

4. Alghamdi SS (2007). Genetic behavior of some selected faba bean genotypes. In African crop Sci Conf Proce 8(1): 709714.

5. Sudarma IK, Aini N \& Wicaksosno KP (2015). Improving of Kidney Bean Production by Plant Spacing in Two Different Altitudes at South Central Timor Regency, Indonesia. On Line $J$ of Biol Sci 15(4): 268.

6. De Almeida Costa GE, da Silva QueirozMonici K, Reis SM \& de Oliveira AC (2006). Chemical composition, dietary fibre and resistant starch contents of raw and cooked pea, common bean, chickpea and lentil legumes. Food Chem 94(3): 327-330.

7. Siddiq M, Ravi R \& Dolan KD (2010). Physical and functional characteristics of selected dry bean (Phaseolus vulgaris L.) flour. LWT-Food Sci Technol 43(2): 232237.

8. Kutos T, Golob T, Kac M \& Plestenjak A (2003). Dietary fiber content of dry and processed beans. Food Chem 80(2): 231235.

9. Beninger CW \& Hosfield GL (2003). Antioxidant activity of extracts, condensed tannin fractions, and pure flavonoids from Phaseolus vulgaris L. seed coat color genotypes. $J$ of Agric and Food Chem 51(27): 7879-7883.

10. Choung MG, Choi BR, An YN, Chu YH \& Cho YS (2003). Anthocyanin profile of Korean cultivated kidney bean (Phaseolus vulgaris L.). $J$ of Agric and Food Chem 51(24): 7040-7043.

11. Granito M Palolini M \& Perez S (2008). Polyphenols and antioxidant activity of Phaseolus vulgaris stored under extreme conditions and processed. LWT 41(5): 994999.

12. Jenkins AL (2007). The glycemic index: Looking back 25 years. Cereal Foods World 52(6): 50-53.

13. Lin LZ, Harnly JM, Pastor-Corrales MS \& Luthria DL (2008). The polyphenolic profiles of common beans (Phaseolus vulgaris L.). Food Chem 107(1): 399-410.

14. Green bean production in (2017), Crops/Regions/World list/Production Quantity (pick lists)", FAO Statistics 2018.

15. Tharanathan RN \& Mahadevamma S (2003). Grain legumes - A boon to human nutrition. Trends Food Sci Technol 14(12): 507-518.

16. Shimelis EA \& Rakshit SK (2005). Proximate composition and physicochemical properties of improved dry bean (Phaseolus vulgaris L.) varieties grown in Ethiopia. LWT 38(3): 331-338.

17. Assefa $T$, Abebe G, Fininsa C, Tesso B \& Al-Tawaha AR(2005). Participatory bean breeding with women and small holder farmers in eastern Ethiopia. World J of Agric Sci 1(1): 28-35.

18. Gepts P, Beavis WD, Brummer EC, Shoemaker RC, Stalker HT, Weeden NF \& Young ND (2005). Report of the Crosslegume advances through genomics conference. Plant Phys 137(4): 1228-1235. 
19. Bode D, Elezi F \& Gixhari B (2013). Morphological characterization and interrelationships among descriptors in Phaseolus vulgaris accessions. Agriculture \& Forestry/Poljoprivreda i Sumarstvo 59(2)

20. Steel RG, Torrie JH \& Dickey DA (1980). Principal and procedure of statistics. $A$ Biometrical approach. Mc Grow Hill. New York 12(3): 633.

21. Ali A, Khan SA, Ali N, Ali S, Hussain I, Raza H, Ahmad F \& Saleem M (2016). Evaluation of locally collected germplasm of common bean (Phaseolus vulgaris L.) for variability in morphological and yield characters in Swat valley. Pure and Appl Biol 5(3): 573.

22. Khan M, Muhammad A, Ahamad N, Khan K, Khan SU \& Chaudhry Z (2015). Variability of Vigour and Viability of Various Varieties of Common Bean (Phaesolus vulgaris L.) Land Races. American-Eurasian J Agric \& Environ Sci 15 (5): 957-961.

23. De Ron AM, Rodiño AP, Santalla M, González AM, Lema MJ, Martín I \& Kigel J (2016). Seedling emergence and phenotypic response of common bean germplasm to different temperatures under controlled conditions and in open field. Frontiers in Plant Sci 2016(7): 1087-1093.

24. Hayat I, Ahmad A, Masud T, Ahmed A \& Bashir S (2013). Nutritional and Health Perspectives of Beans (Phaseolus vulgaris L.). Critical Rev in Food Sci and Nutr 54(5): 580-592.

25. Wani IA, Sogi DS, Wani AA \& Gill BS (2017). Physical and cooking characteristics of some Indian kidney bean (Phaseolus vulgaris L.) cultivars. J of the Saudi Soc of Agric Sci 16(1): 7-15.

26. Nassar RM, Ahmed YM \& Boghdady MS (2010). Botanical Studies on Phaseolus vulgaris L. morphology of vegetative and reproductive growth. Inter. $J$ of Bot 6(3): 323-333.

27. Emilian M, Sorin C, Giancarla V, Lavinia S, Constantin A, Nicoleta B \& Dorin RI (2014). Study regarding the variability of the pods productivity of a Phaseolus vulgaris var. nanus landraces. 48th Croatian \& 8th
International Symposium on Agriculture Dubrovnik, Croatia, pp 754-759.

28. Tamado T, Fininsa C \& Worku W (2007). Agronomic performance and productivity of common bean (Phaseolus vulgaris L.) varieties with double intercropping in maize (Zea mays L.) in eastern Ethiopia. Asian J of Plant Sci 6(5): 749-756.

29. Yuste-Lisbona FJ, González AM, Capel C, García-Alcázar M, Capel J, De Ron AM, Santalla M \& Lozano R (2014). Genetic variation underlying pod size and color traits of common bean depends on quantitative trait loci with epistatic effects. Mol Breeding 33(4): 939-952.

30. Chhetri A \& Bhatta A (2017). AgroMorphological Variability Assessment of Common Bean (Phaseolus vulgaris L.) Genotypes in High Hill Jumla, Nepal. Inter $J$ of Env Agric and Biotech 2(6): 133-139.

31. Canci H, Yeken MZ, Kantar F, Bozkurt M, Ciftci V \& Ozer G (2019). Assessment of variation in seed morphological traits in Phaseolus sp. landraces from western Anatolia. Banat's J of Biotechnol 10(19): 75-88.

32. Shahid A (2011). Variability, correlation and path analysis for seed yield and yield related traits in common beans. Indian $J$ of Hortic 68(1): 56-60.

33. Chen Y, Zhang H, Liu R, Mats L, Zhu H, Pauls KP, Deng Z \& Tsao R (2019). Antioxidant and anti-inflammatory polyphenols and peptides of common bean (Phaseolus vulga L.) milk and yogurt in Caco-2 and HT-29 cell models. J of Func Foods 53: 125-135.

34. Ombra MN, d'Acierno A, Nazzaro F, Riccardi R, Spigno P, Zaccardelli M, Pane C, Maione M \& Fratianni F (2016). Phenolic composition and antioxidant and antiproliferative activities of the extracts of twelve common bean (Phaseolus vulgaris L.) endemic ecotypes of southern Italy before and after cooking. Oxidative Med and Cell Long 20(1): 161-165.

35. Mastura, HY, Hasnah H \& Dang TN (2017). Total phenolic content and antioxidant capacity of beans: organic vs inorganic. Inter Food Res J 24(2): 510-517. 